\title{
Managing the Paradigm Shift to E-Learning in Distance Education (A Case Study at CoDE, UCC)
}

\author{
Article by Nelly Abaidoo and Valentina Arkorful \\ College of Distance Education, University of Cape Coast, Ghana \\ E-mail:nellymenz@yahoo.com,valentinaabaarkorful@yahoo.com
}

\begin{abstract}
This study sought to find out how e-learning staff in the College of Distance Education of University of Cape Coast (CoDE, UCC) are prepared and vested in the management of paradigm shift to e-learning. Diagrams of Educational Management Paradigm of the past and that of today were looked at. There have been a number of earlier comparative studies e.g. Peter's(2003) which indicate that paradigm shift includes a transition from modern curricula to post-modern curricula. The population for the study consisted of all 15 staff of CoDE in UCC who are managing the e-learning platform. All the 15 staff were used as the sample for the study. The instrument used for data collection was an interview guide. Data were analysed using themes. All the respondents agreed that e-learning platform is a forum for knowledge sharing and it is also a space for collaboration and interactivity. They also agreed that the Goal of e-learning is to create a transformative learning environment. They also stated that they have the skills in implementing e-learning at CoDE in UCC. However, their main challenges were that students are not given the chance to control e-learning platform. It is recommended that staff should be very clear about their multiple roles they are prepared for and take on while implementing e-learning. The staff should also have the corresponding changing role-related skills and competencies in order to provide high quality platform for distance learners.
\end{abstract}

Key words: CoDE, UCC, paradigm shift, e-learning, transition modern curricula, postmodern curricula, e-learning platform, role-related skills.

\section{Introduction}

The way in which learning is experienced has begun to change. Technology is impacting education to such an extent that educators and industry-professionals are claiming a revolution is underway. Students are no longer restricted to hierarchical, top-down, traditional learning environments. Increasingly, students are offered an individualized and adaptive form of education that can be accessed anywhere and at any time. This change in the learning experience could not have come at a better time.

The new generation of students are increasingly 'digital natives' (Prensky, 2001), who view technology as a non-remarkable feature of daily-life. The impact of technology in education is no longer new and exciting; it has become merely a necessity. In the last decade, distance education has developed in two major directions: the individual flexible teaching model and the extended classroom model (Rekkedal \& Dye, 2007). The former allows students to start the class at any time, study in isolation and communicate with instructors and classmates through asynchronous tools. The latter organizes students into groups, requires them to meet at local study centre, and allow them to use interactive technologies such as video conferencing to interact (Rekkedal \& Dye, 2007).

Due to the rapid development of technology, courses using a variety of media are being delivered to students in various locations in an effort to serve the educational needs of growing populations. In many cases, developments in technology allow distance education programs to provide specialized courses to students in geographically remote areas with increasing interactivity between students (Fahad, 2009).

The College of Distance Education (CoDE) of the University of Cape Coast (UCC) has therefore become a stepping stone by providing Huawaii Tablets to their students as a way of 
South American Journal of Academic Research

Special Edition May 2016

integrating E-learning in their curriculum. Students in online courses expect guidance in four domains: the technical-operational domain, task-oriented domain, personal-emotional domain, and the social domain. Moreover, it was found that within distant learning course where face-to-face meetings are absent, the need for guidance with "personal emotional significance" is amplified. Therefore, the study seeks to find out how E-learning staff in CoDE UCC are prepared and vested in the management of paradigm shift to E-learning. The research seeks to determine:

1. Staff perception towards adopting an e-learning platform.

2. Staff skills in using e-learning platform.

3. Challenges staffs are likely to face when using e-learning system.

\section{Review of Related Literature}

The term paradigm shift is being used often in the $21^{\text {st }}$ century. The paradigm shift in distance education refers to the transition process. New concepts, models and terms are different from the old ones. Paradigm shift in distance education means substitution of the new educational terms with the old ones. This paradigm shift includes a transition from modern curricula to post-modern curricula and also includes a transition from traditional learning to digitized formats of learning (Peters, 2003). This paradigm shift is about a shift from tutor centered teaching to a learner centered learning.

The educational management paradigms of past and today primarily have focused upon the interaction between instructors, learners and subject matters. Naturally, the structure and the developments in the surrounding society play an important role as far as models transition from one model to another are concerned. The models may be looked upon as changes of paradigms assuming new forms in connection with the implementation of new discoveries or theories and changes in views and attitudes (Sigri \& Nielsson, 2003).

The educational management paradigm of the past describes the interaction among instructors, learners and education/training contents viewed from educational/teaching traditions of the past (Figure-1). To a very great extent, this situation was characterized by a verbal flow, streaming from the instructor directly to the learner. The instructor possessed all existing knowledge and experience, and he/she alone decided in which way knowledge should be transmitted. In fact, the concept unfortunately may lack internal coherence and connection to anything the learner already knows (Amig, 2001).

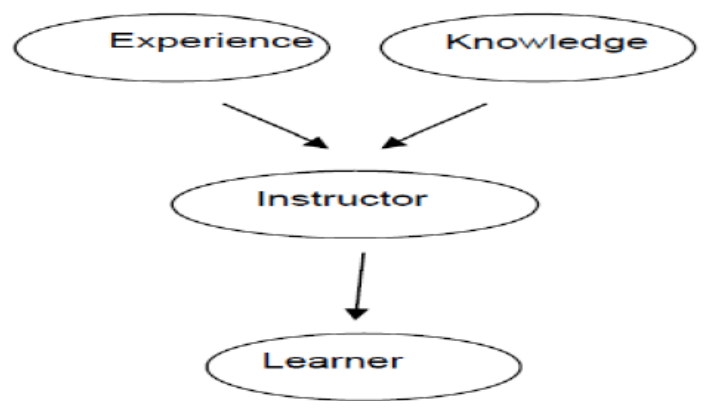

Figure 1: The Educational Management Paradigm of the Past

Source: Sigri, U., \& Nielsson, L. (2003).

The educational paradigm of today shown in Figure 2 is an expression of how interaction between instructor, learners and contents are experienced. Still the instructor plays a central role and the main part of the communication is based upon the instructor's knowledge and experience. The communication is two-ways and it takes place both between the instructor and the learner as well. The responsibility is a bit more differentiated from the past paradigm. Both instructor and learners are responsible in the teaching process (Husmann \& Miller, 2001). 


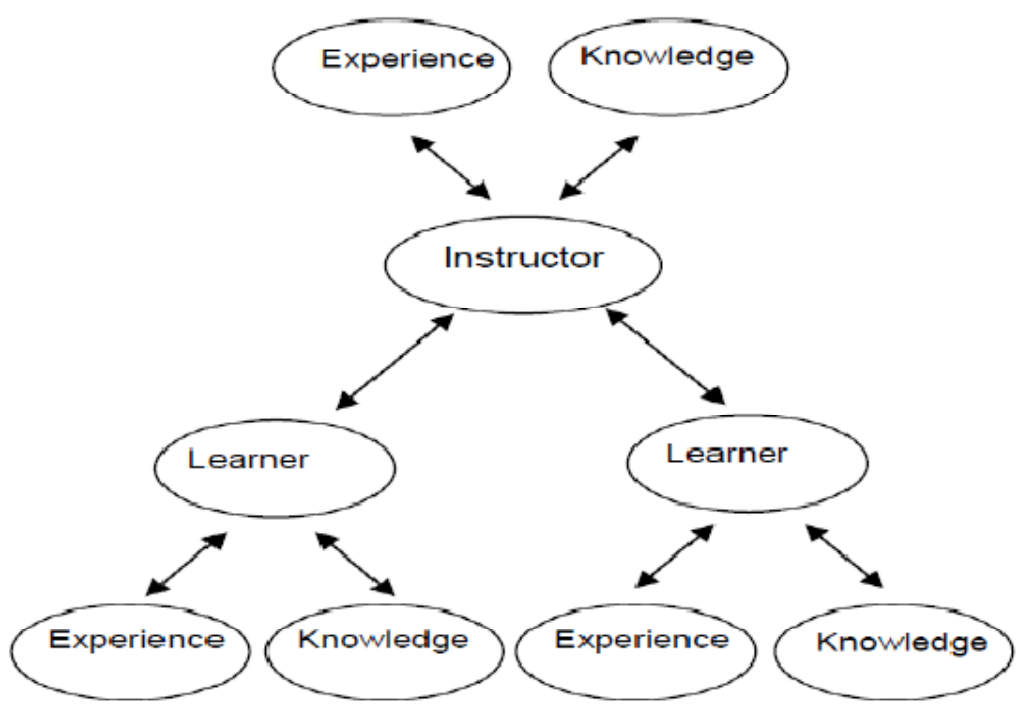

Figure 2: The Educational Management Paradigm of Today

Source: Sigri, U., \& Nielsson, L. (2003).

The educational paradigm of tomorrow shown at Figure-3 may already be experienced as a fact in great parts of the highly civilized world. One might call it "e-learning based" paradigm with the "management knowledge base" (learning resource centre) element in which the phrase "e-learning" has to be perceived as "information technology" (Sigri \& Nielsson, 2003). Here we experience an essential difference from the two other paradigms.

The knowledge base (learning resource centre) is placed in the centre, and the instructor's role as well as the learners' roles is equally important for the learning process. The communication is two-ways between instructor and learning resource centre, instructor and learners and among learners themselves. In comparison with the two other paradigms the general idea now is to place the responsibility upon the shoulders of the learners (Crumpacker, 2001).

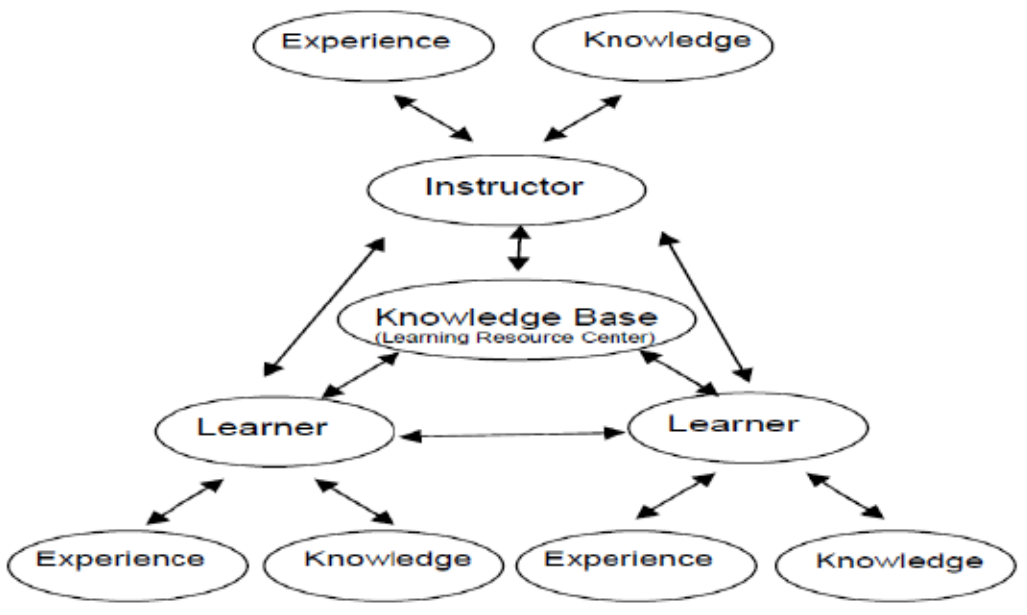

Figure 3: The Educational Management Paradigm of Future

Source: Sigri, U., \& Nielsson, L. (2003).

The new educational management paradigm stresses the importance of "learning resource centre" (LRC) which is a place where learners may go to locate instructional materials and use equipment to solve a problem or fulfill a learning objective. Furthermore, a specific 
South American Journal of Academic Research

Special Edition May 2016

clarification with regard to technological capacities and limitations is required, in order that teaching processes are accomplished in appropriate way. The new educational management paradigm with learning resource centre expresses a "searching-responsibility" of the learners unlike the "receiving-responsibility" of the earlier paradigms. In a pedagogic sense of the words one must distinguish between actually attending a series of lectures with only limited or no dialogue and the kind of teaching in which learners actively participate in the learning process, including problem identification, discussions, identification of key issues, individual learners research in connection with the gathering of information of specific issues (Sigri \& Nielsson, 2003).

\section{Technological Components of Distance Education}

Components of distance education are changing. Distance learning environments are becoming highly interactive and are being supported by hybrid networks and virtual classrooms (Williams, Paprock \& Covington, 1999). Audio, video, digital multi-media (including audio, video and incorporating text), texts (including still graphics) and direct (face to face) human contact are the most important media that are used in distance education (Bates, 2005).

Punnie and Cabrera (2006) specified some technological trends that will shape the future of knowledge society and they are:

1. Broadband Internet access which is becoming more widespread, especially in welladvanced economies, driven by peer-to-peer file sharing and features.

2. Weblogs or blogs which are becoming a major source of information and communication for internet users.

3. Podcasting could be a driver for mobile learning.

4. Short Message Services (SMS) and the Multimedia Messaging Services (MMS) which are also becoming important providers of new content and offer ways for people to be mobile and share information.

5. Open source software and open source content which are challenging existing software and content developers, including educational institutions are integrating them into their curriculum.

Social software and Web 2.0 are also the new technological components of distance education. This new concepts are shaping the educational goals in e-learning. Anytime, anywhere flexible and high-quality learning environments containing well organized support services are the main expectation of students in the information age (Khan, 2007). Therefore, social software can be used in education in the process of changing goals and expectations. For this reason some key characteristics of social software that must be analysed for distance education are indicated below by Owen, Grant, Sayers and Facer, (2006):

1. Social software delivers communication between groups.

2. Social software has new tools for creation of knowledge.

3. Social software enables communication between many students.

4. Social software provides sharing resources.

5. Social software assists personalization of priorities.

6. Social software delivers collaborative indexing and collecting information.

Rapid developments in social software technologies such as wikis have enormous reflections in educational organizations. Developing, editing, reorganizing facilities of web based content provide students to share knowledge with their friends and their teachers. Therefore social software have role to develop collaboration between students (Choy \& Ng, 2007). Weblogs, Flickr, deli.cio.us as photo or bookmarking systems, MySpace, YouTube and Facebook as an example of sites are the popular trends to develop and share information with society. These collaborative tools have emphasized the importance of social software for all organizations (Minocha, Schenks, Sclater, Thomas \& Hause, 2007).

Basic principles of Web 2.0 and Social software can be summarized by three dimensions according to Huertas, Casado, Corcoles, Mor and Roldan (2007): 
1. Student- center design: Students can develop their own knowledge.

2. Teachers and students as peers in a social network.

3. A transition process.

\section{Methodology}

Descriptive research was deemed appropriate for the study because it involved collection of data in order to answer questions concerning the subject matter under study. The respondents selected for the study was sampled using census sampling technique and consisted of all 15 staff of Code Master of Education (Information Technology) Department in UCC who are managing the e-learning platform. The instrument for data collection was an interview guide. An interview is a managed verbal exchange (Ritchie \& Lewis, 2003). Data were anaysed using themes.

\section{Results and Discussion}

Quotations and quotes were used to confirm statements to give statistical reflections on key issues in terms of the research questions. The demographic characteristics considered in the study are sex, age, marital and educational level. The demographic characteristics of the respondents helped in determining the extent to which the responses they provided could be depended upon. Fifteen respondents were interviewed.

The demographic characteristics of the staff revealed that there were $(70 \%)$ of male to (30\%) female, indicative of gender bias. This shows that males dominated females in the study.

Five (22.7\%) of the respondents felt between $20-25$ age bracket, 4 (20.3\%) of them fell in the 26 - 30 age bracket and 2 (18.3\%) of them fell in 31 - 35 age bracket. The remaining 4 (20.3\%) fell in the 36 - 40 age bracket. The age distribution of the respondents shows that they were mature enough. One may therefore conclude that they would be able to express their opinion and views as to what e-learning entails.

On the educational background of the respondents, it was seen from the data gathered from the interviews that second degree holders constitute the bulk of interviewees having their masters in Information Technology and Computer Science. The duties of staff in e-learning require people with great knowledge and expertise in computing.

\section{Perception of staff towards adopting of an e-learning platform}

In trying to answer the research question, staff were asked what they see e-learning platform. Almost all of them answered that e-learning forum is for knowledge sharing, the content in the existing e-learning system can only be modified by staff, e-learning space is for collaboration and interactivity, the current e-learning system did not allow students to control their learning environment and e-learning limits peer to peer interactivity. Based on the findings, most of the staff has a moderate positive perception towards e-learning. From the findings, e-learning forum captured most of the staff attention due to its interactivity functions in e-learning system. Most of them believe that e-learning forum is an open space for instructional discussion. The findings of the study also support the work of Tasir, Al-Dheleai and Shukor (2014) on perception of staff towards e-learning platform in Malaysia.

Additionally, report by Gilcher \& Johnstone (2009) also provides evidence that staff attitudes improve as experience with distance education increases, and as instructors become more familiar with the technology and logistics of distance teaching, and then they have positive perception on e-learning platform.

\section{Staff skills in using e-learning platform}

The goal of e-learning is to create a transformative learning environment. This means using innovative techniques and a variety of resources in the learning process. A transformative approach to online learning may result in increased reflection due to writing and peer interaction and improved problem solving and critical thinking due to peer modeling and 
South American Journal of Academic Research

Special Edition May 2016

mentoring (Mayes, 2011). Respondents were asked if they have the needed skills in e-learning to achieve this.

The interviewees further stated their skills in implementing e-learning. Some qualitative comments noted from staff interviewed were; Experience of using online discussion tools, experience of internet navigation, downloading and uploading files through internet, using weblogs or blogs interface and using podcasting.

\section{Challenges staffs are likely to face when using e-learning system}

A challenge is anything that retards the progress of any set objective. Students faced problems in the e-learning system because information is seldom updated by lecturers. They can control their e-learning environment well if developers and staff update their e-learning platform.

The respondent interviewed indicated that students will not be given the chance to control the e-learning platform. Therefore, further action should be taken where students should be given more control on the e-learning content. They should be given the control to select and present the tasks and content, as well as the transfer process, according to their needs and preferences. The findings of the study also support the work of Stray and Totter (2006).

According to the respondents, the primary challenge in distance teaching include the inability to reach new populations of learners, the lack of opportunity to work with better prepared and more motivated students, no flexibility in work schedule, and the inability to use a broader range of media-based resources to support e-learning in distance education.

Again, they stated that another challenge is that the learner characteristics required for the online student can create obstacles to both teaching and learning. For example, some students are used to learning through interaction in the classroom. They may find that an online course in e-learning does not provide them with the support they are used to.

Another study by Attwell (2007) also indicated staff poor tendency to create and have more control of their learning environment with lecturers' role as a facilitator and adviser and the features provided by e-learning as a major challenge staff face when using e-learning platform. This result is in contrast with the finding by DeVries and Rugg (2004) who listed different challenges staff face when using the e-learning platform. They stated that one of the initial problems with teaching via videoconferencing using e-learning still is the poor quality of the picture, even in the best of ISDN systems. Staff first needs to get used to the "jerky" pictures inferior to the TV picture before they can start coping with the real educational aspects of the situation. Desktop video conference systems are even worse in this respect.

\section{Recommendations}

1. Staff should be very clear about the multiple roles they should prepare for and take on while implementing e-learning, have the corresponding changing role-related skills and competencies in order to provide high quality platform for distance education learners.

2. Teaching at a distance can be a pleasurable experience for everyone involved, staff and student alike. Staff maintaining e-learning platform should make it interesting to motivate learners to remain active, thereby making it a valuable learning experience as well as fun.

3. Staff managing the e-learning platform should use synchronous conferencing tools that will enable students to bring more issues to their attention as well as to their peers as they interact and provide just-in-time course feedback.

4. If e-learning is to have a meaningful role in higher education, it is important that universities focus on students' attitudes and their expectations with regard to the role of e-learning within the higher education experiences. 


\section{References}

[1] Anderson, T. (2005). Distance learning - Social software’s killer app? Retrieved: September 18, from: http://www.unisa.edu.au/odlaaconference/PPDF2s/13\%20odlaa\%20Anderson.pdf

[2] Arsun, O. I. \& Kuru, S. (2006) Innovative, Inclusive, Interactive \& Intercultural learning campus Draft Exploitation Model. In: O.I. Arsun \& S. Kuru (edt.) Retrieved: March 12, 2007 from:http://edu.wuwien.ac.at/icamp/fileadmin/deliverables/D5.2_icamp_exploitation- model- draft.pdf

[3] Bates, T. (2005). Technology e-learning and Distance Education.(2nd Edition). Newyork, Routledge.

[4] Beaudoin, M. (1990) The Instructor's Changing Role in Distance Education. The American Journal of Distance Education, 4(2), (1990)

[5] Berge, Z. L. (1992). The Role of the Online Instructor/facilitator Retrieved from http://www.emoderators.com/moderators/teach_online.html

[6] Borja, B. and Rhea R. (2005). Cyber Schools’ Status. Education Week.1 (24)35.

[7] Bracher, M. (2009). Radical Pedagogy: Identity, Generativity, and Social Transformation. New York \& Hampshire: Palgrave Macmillan.

[8] Darmaningtyas (D.E.) \& Subkhan, E. (2012). Manipulasi Kebijakan Pendidikan. Yogyakarta: Resist Book.

[9] Davis, N.E. \& Roblyer, M.D. (2005). Preparing Teachers for the Schools That Technology Built. Journal of Research on Technology in Education. 3(7)4.

[10] De Lissovoy, N. (2008). Power, Crisis, and Education for Liberation: Rethinking Critical Pedagogy. New York \& Hampshire: Palgrave Macmillan.

[11] Feenberg, A. (2002). Transforming Technology: A Critical Technology Revisited. Oxford: Oxford University Press.

[12] Freire, P. (2005). Pedagogy of the Oppressed. 30th Anniversary Edition. New York \& London: Continuum.

[13] Garrison, D. R. and Shale, D. "Mapping the Boundaries of Distance Education: Problems in Defining the Field”, American Journal of Distance Education, (1)1, (1987)

[14] Gray, D. L. "Virtual High Schools: A Case Study to Explore Why Students, Parents, and Teachers Choose This Type of Alternative Education”, Doctorial Dissertation, University of Denver, (2005) "K-12 Issues News, Reviews, Resources, and Tools Technology Teaching”, retrieved from http://www.distanceeducator.com/k12/

[15] Keegan, D. "Problems in Defining the Field of Distance Education", American Journal of Distance Education, 2(2), (1988)

[16] Knowles, M.S. “The Modern Practice of Adult Education: From Pedagogy to Andragog”, Prentice Hall, Englewood Cliffs, NJ, (1980)

[17] Moore, M. G. and Anderson, W. G., "Handbook of Distance Education”, Mahwah, NJ, (2003)

[18] Moore, M. G. “Constructivists: Don’t Blame the Tools”, American Journal of Distance Education (18)2, 6772, (2004)

[19] Moore, M. and Kearsley, G., “Distance Education A Systems View”, Thomson Wadsworth, (2005)

[20] Muirhead, B. "Practical Strategies for Teaching Computer-Mediated Classes”, Ed Journal (15)50(2001),retrievedfromhttp://www.usdla.org/html/journal/may01_Issue/article02.htl.

[21] Rothermel, M. “Development and Management of Virtual Schools: Issues and Trends”, The Quarterly Review of Distance Education (6)2, pps 173-176, (2005)

[22] Sellers, R. "Learning to Teach in a Virtual Environment: A Case Study of the Louisiana Virtual Classroom Teachers”, Doctoral dissertation, Louisiana State University, (2001)

[23] Sherry, L. "Issues in Distance Learning”. International Journal of Educational Telecommunications 1(4), 337-365, (1995)

[24] Smith, T. C., “Fifty-One Competencies for Online Instruction”, Journal of Educators Online, (2)2, (2005)

[25] Tam, M. "Constructivism, Instructional Design, and Technology: Implications for Transforming Distance Learning”, Educational Technology and Society (3)2, (2000)

[30] Wolf, P. D. “Best Practices in the Training of Faculty to Teach Online”, Doctorial Dissertation, University of Maryland, (2004) 